\title{
Psikolojik Danışma Merkezine Başvuran Üniversite Öğrencilerinin Depresyon, Sosyal Kaygı, Durumluk ve Sürekli Kaygı Düzeylerinin İncelenmesi
}

\author{
DOI: $10.26466 /$ opus. 904430
}

\author{
Hülya Şahin Baltacı*-Deniz Küçüker**-Uğur Yiğit Karataş*** \\ Iş1 Özkılıç***-Hilal Asena Özdemir***** \\ * Prof. Dr., Pamukkale Üniversitesi, Denizli/Türkiye \\ E-Posta: $\underline{\text { hbaltaci@pau.edu.tr }}$ \\ ORCID: $\quad$ 0000-0001-7825-4252 \\ ** Öğretim Gör., Pamukkale Üniversitesi, Denizli/Türkiye \\ E-Posta: dkucuker@pau.edu.tr \\ ORCID: $\quad$ 0000-0002-1105-7470 \\ *** Yl. Öğr., Pamukkale Üniversitesi, Denizli /Türkiye \\ E-Posta: uguryigit20@gmail.com \\ ORCID: $\quad$ 0000-0003-4182-0331 \\ **** Öğretim Gör., Pamukkale Üniversitesi, Denizli/Türkiye \\ E-Posta: \\ iozkilic@pau.edu.tr \\ *****Yl. Öğr., Pamukkale Üniversitesi, Denizli/Türkiye \\ E-Posta: hilal.asenaozdemir@bahcesehir.k12.tr
}

Öz

Bu araştırmanın amacı, psikolojik danışma merkezine başvuran üniversite öğrencilerinin depresyon, sosyal kayğ, durumluk ve sürekli kaygı düzeylerinin, intihar düşünceleri, psikiyatrik tamı alı alma ve sinıf düzeylerine göre farklllk gösterip göstermediğini incelemektir. Araştırma grubunu, 341'i kadın ve 98'i erkek olmak üzere üniversite psikolojik danışma ve rehberlik merkezine başvuran toplam 439 üniversite öğrencisi oluşturmaktadır. Araştırma grubunda yer alan öğrencilerin \%17.1'inin minimal, \%21'inin hafif, \%42.4'ünün orta ve \%19.6'ssnın şiddetli düzeyde depresyon; \%1.8'inin çok düşük, \%23.5'inin düşük, \%40.2'sinin orta, \%23.5'inin yüksek ve \%10.9'unun çok yüksek düzeyde sosyal kaygl; \%32'sinin düşük, \%44.6'sının orta, \%19.4'ünün yüksek ve \%3.9'unun çok yüksek durumluk kaygı, \%15.7'sinin düşük, \%46.1'inin orta, \%32.9'unun yüksek ve \%5.3'inin çok yüksek düzeyde sürekli kaygısı bulunmaktadır. Ayrıca, katılımclarn, \%19.1'inin psikiyatri servisine sevk edildiği, \%21.4'ünün intihar düşünceleri taşıdığı, \%36'sınn psikiyatrik tanısının olduğu görülmüş̧ür. Araşstrmada veri toplama araçları olarak Başvuru Formu, Beck Depresyon Envanteri, Liebowitz Sosyal Fobi Ölçeği ve Durumluk ve Sürekli Kayğ Ölçeği kullanılmıştır. Verilerin analizinde t-testi ve Tek Yönlü Varyans Analizi (ANOVA) kullanılmıştır. Araştırma bulgularına göre, intihar düşüncesine sahip olanlarn depresyon, sosyal kaygı ile sürekli ve durumluk kaygı düzeylerinin intihar düşüncesi olmayanlardan daha yüksek olduğu bulunmuştur. Bir diğgr bulguya göre, geçmişte psikiyatrik tanı alanlarn depresyon, sosyal, durumluk ve sürekli kaygı düzeylerinin psikiyatrik tanısı olmayanlara göre anlaml olarak daha yüksek olduğu görülmüştür. Son olarak sinıf düzeylerine göre, birinci ve ikinci sinı üniversite öğrencilerinin yüksek düzeyde depresyon, sosyal, durumluk ve sürekli kaygr deneyimlediği ortaya konmuştur. Bu araştırma Pamukkale Üniversitesi Sosyal ve Beşeri Bilimler Etik Kurulu tarafindan onaylanmıştır (23.12.2020; 12-6)

Anahtar Kelimeler: Depresyon, sosyal kaygı, durumluk kaygı, sürekli kaygı, intihar. 


\title{
Investigation of Depression, Social Anxiety, State and Trait Anxiety Levels of College Students Applying to Counseling Center According to Suicidal Thoughts and Psychiatric Diagnosis
}

\begin{abstract}
The aim of this study is to examine whether depression, social anxiety, state anxiety, and trait anxiety levels of college students who applied to a counseling center differ according to their suicidal thoughts, psychiatric diagnosis, and class standing. Research group consists of a total of 439 college students, 341 women and 98 men. Counseling Center Application Form, Beck Depression Inventory, Liebowitz Social Phobia Scale, and State and Trait Anxiety Scale were used as data collection tools in the study. To test the aims of the research, $t$-test, ANOVA, and descriptive statistics were used in data analysis. According to the findings, it was observed that $17.1 \%$ of the students had minimal depression, $21 \%$ had mild, $42.4 \%$ had moderate and $19.6 \%$ had severe depression; $1.8 \%$ had very low social anxiety, $23.5 \%$ had low, $40.2 \%$ had moderate, $23.5 \%$ had high and $10.9 \%$ had very high social anxiety; $32 \%$ had low state anxiety, $44.6 \%$ had moderate, $19.4 \%$ had high and $3.9 \%$ had very high state anxiety, $15.7 \%$ had low trait anxiety, $46.1 \%$ had moderate, $32.9 \%$ had high and $5.3 \%$ had very trait anxiety. It was found that $19.1 \%$ of the participants were referred to a psychiatric service, $21.4 \%$ had suicidal thoughts, $36 \%$ had a psychiatric diagnosis previously. In addition, it was revealed that those who have suicidal thoughts show a significant difference in favor of those who have suicidal thoughts when compared with those who do not have suicidal thoughts in terms of research variables. It was revealed that those who had a psychiatric diagnosis in the past showed a significant difference in terms of study variables in favor of those who had a psychiatric diagnosis compared to those who did not have a psychiatric diagnosis in the past. Finally, it was observed that depression, social anxiety, state, and trait anxiety levels differ significantly according to class standing. This research was approved by Pamukkale University Social and Human Sciences Ethics Committee (23.12.2020; 12-6).
\end{abstract}

Key Words: Depression, Social anxiety, State anxiety, Trait anxiety, Suicide. 


\section{Giriş}

Üniversiteler topluma faydalı olabilecek bireyleri yetiştirmenin amaçlandığ1 eğitimdeki en üst kurumdur (Yeşilyaprak, 1985). Üniversite yılları bireylerin birçok yeni yaşantı ile karşılaştığı önemli gelişim dönemlerinden biridir. Gelişimsel evre modellerinin öncülerinden olan Erik Erikson'ın bireylerin doğumdan yetişkinliğe kadar sekiz gelişim evresi boyunca ilerlemelerini kapsayan bir teoriye göre üniversite yılları, gelişimin altıncı aşaması olan genç yetişkinlik bireylerin yakın, sevgi dolu ilişkiler kurmaya ihtiyaç duydukları bir dönemi işaret eder. Yakınlığa karşı yalıtılmışlık dönemindeki bireyler, başkalarıyla içten ve anlamlı bağlar ararken diğer yandan sosyal izolasyonla savaşırlar (Yazganİnanç- ve Yerlikaya, 2014). Bu gelişim dönemindeki bireylerin büyük kısmı için bu geçiş bir diğer bireye bağlılık sözü verme ve/veya aile kurma arzusuyla kendisini gösterir. Yakınlık ile sosyal izolasyon arasındaki çelişkiyi kişilerarası ilişkiler içerisinde çözmeye çalışmanın üniversite döneminin son yıllarında bireyi bekleyen gelişimsel bir mücadele olduğu söylenebilir (Deges-White ve Borzumato-Gainey, 2013). Başka bir ifade ile üniversite öğrencileri gelişimsel zorluklarla karşı karşıya kalmaktadirlar.

Üniversite yılları, öğrencilerin çoğu için stresli ve baş etme mekanizmalarını zorlayan bir zaman dilimidir. Genç yetişkinler, ebeveynlerden ayrılma, kişisel ilişkiler kurma, bağımsız yaşama ve kendi öz kimliklerini keşfetme gibi birçok gelişimsel değişiklik ve zorlukla karşılaşmaktadır (D'Amico, Mechling, Kemppainen, Ahern ve Lee, 2016). Özellikle birinci sinıf öğrencileri memleketlerinden uzakta bir yaşam sürmek, üniversite hayatına uyum sağlamak, yurtta başkalarıyla birlikte ortak bir alanı paylaşmak, zamanı etkili kullanmak veya bütçelerini yönetmek gibi zorluklarla karşı karşıya kalmaktadır. Her ne kadar üniversite dönemine geçişte karşılaşacakları fırsatlar yeni üniversiteye başlamış olan öğrencileri heyecanlandırsa da psikiyatrik bozukluklar için de risk altında bırakan veya önceden var olan sorunları daha da kötüleştirebilecek durum ve beklentilere de bu geçiş döneminde maruz kalmaktadırlar.

Üniversite öğrencilerinin dörtte üçünden fazlasının herhangi bir psikiyatrik tanısı bulunmamaktadır, ancak yarıdan azı (\%49.2) akıl sağlığı açısından değerlendirildiğinde sağlıklı kabul edilen grupta yer almakta- 
dır. Psikiyatrik tanısı olmayanların oranının yüksekliği, bu öğrencilerin akıl sağlığı kriterleri açısından değerlendirildiğinde sağlıklı kabul edilen gruba girmeleri anlamına gelmemektedir. Öte yandan psikiyatrik tanısı olan öğrenciler arasında akıl sağlığı açısından sağlıklı kabul edilen grup ile orta düzey sağlıklı ve düşük düzey sağlıklı gruplar arasında da intihar riski bakımından aynı ilişki bulunmuştur (Keyes vd., 2012). Literatürdeki bir çalışmada yaklaşık olarak her üç birinci sınıf öğrencisinden birinin, akademik işlevselliğin azalmasıyla ilişkili içsel ve dışsal akıl sağlığ 1 problemleri rapor edilmiştir (Burffaerts vd., 2018). Buradan hareketle akıl sağlığı sorunlarının üniversite birinci sınıfta yaygın olduğu ve daha düşük akademik işleyiş ile açıkça ilişkili olduğu söylenebilir. İlgili literatür incelendiğinde yükseköğrenim gören öğrencilerin akıl sağlığını ölçmeye yönelik yapılan araştırmaların yaygınlığı göze çarpmaktadır (Beiter, 2015; D'Amico, 2016; Lee, Dickson, Conley ve Holmbeck, 2014; Nordstrom, Swenson Goguen ve Hiester, 2014; Şart, Börkan, Erkman ve Serbest, 2016; Joeng, 2015; Weigold ve Robitscheck, 2011). Özetle, üniversite öğrencilerinin akıl sağlığına ilişkin problemlerle karşı karşıya geldikleri ve özellikle yeni yaşantılarla karşılaşan geçiş dönemindeki birinci sınıf öğrencilerinin bu noktada risk altında oldukları söylenebilir.

Geçiş döneminde üniversite yaşamına uyum, bazı öğrenciler için hızlıca gerçekleşirken, bazı öğrenciler için üniversitenin ilk yıllarına yayılan daha karmaşık bir süreç izleyebilir. Özellikle bu süreci karmaşık yaşayan öğrencilerde genellikle stres ile karakterize olan ve depresif belirtilerin ilerleyebildiği veya şiddetlenebildiği görülmektedir (Lee, Dickson, Conley, Holmbeck, 2014). Başka bir ifadeyle üniversite öğrencilerinin büyük çoğunluğu, uyum zorluklarıyla baş ederek üniversite hayatının zevklerini ve yeniliklerini deneyimleyebilse de önemli sayıda üniversite öğrencisi de bu geçiş yıllarında şiddetli depresyon yaşar. Üniversite öğrencileri ile yapılmış olan çalışmalarda önemle vurgulanan psikolojik rahatsızlıklardan birinin depresyon olduğu ortaya konmaktadır (Sherer, 1985; Bumbery, 1978). Nitekim en yüksek depresyona sahip olan öğrencilerin de yatay geçişle gelenler, son sınıflar ve kampüs dışında yaşayanlar olduğu ortaya konmuştur (Beiter vd., 2015). Ceyhan ve Ceyhan (2011) birinci sınıfların, diğer sınıf düzeyi (ikinci, üçüncü ve dördüncü) öğrencilerinin tümünden anlamlı biçimde daha yüksek yalnızlık ve depresyon düzeyine sahip olduğunu ortaya koymuştur. İlgili alanyazın incelendi- 
ğinde üniversite öğrencinin en çok karşılaştıkları problemlerin başında depresif belirtiler olduğu sonucuna varılmıştır (Özbay, 1997: Deniz, Avşaroğlu ve Hamarta, 2004).

Üniversite öğrencilerinin sıklıkla karşılaştıkları akıl sağlı̆̆ı problemlerinden biri de intihar düşünceleridir. Nitekim öğrenciler arasında intihar düşünceleri ve girişimlerinin yaygin olduğu bilinmektedir (Mortier vd., 2015). İntihar girişimi nedenleri incelendiğinde okul stresinin, ilişki sorunlarının, aile problemlerinin, depresyon, umutsuzluk, kaygı ve maddi stresin öne çıkan faktörler olduğu görülmüş olup öğrencilerin \%24'ünün üniversitede intihar girişiminde bulunmayı düşündüğü, \%5'inin ise intihar girişiminde bulunduğu ortaya konmuştur (Westefeld vd., 2015). İntihar düşünceleri ve intihar girişimleri artıyor gibi görünmekle birlikte aslında gerçekleşen durum daha fazla öğrencinin intihar girişimlerini bildiriyor olması da olabilir. Üniversite öğrencilerinde artan intihar düşüncelerini tespit etmek, üniversite kampüslerinde intihar girişimlerinin ve ölümlerinin önlenmesinde kritik bir adımdır. Her ne kadar intihar düşüncesi şiddetli depresyonu olan öğrencilerde en üst düzeyde olsa da yalnızca şiddetli depresyonu olan öğrencilerin intihar için risk grubunda olduğunun varsayılmaması gerekir. Cukrowicz, Cheavens, van Orden, Ragain, Cook (2011) tarafından yürütülen bir çalışmada hafif ve orta derecede depresif belirtileri olan üniversite öğrencilerinin de intihar düşüncelerine sahip olabildiği ortaya konmuştur. Bütün bunlar bir arada değerlendirildiğinde özellikle üniversite öğrencileri oldukça zorlayıc1 yaşantılarla karşılaştı̆̆ 1 ve bu yaşantılar karşısında da yaşamlarına son vermeyi düşünecek kadar baş etmekte güçlük çektikleri sonucuna varılabilir.

Son olarak üniversite öğrencilerinin karşılaştığ 1 problemlerden biri de kaygıdır. Kaygı; insanların dışsal ve psikolojik durumlara ilişkin verdiği duygusal tepkiler bütünüdür (Öner, 1990). Üniversite öğreniminin ilk yılları, öğrencilerine ilişkin kaygı belirtilerinin görüldüğü çalışmalara rastlanmaktadır (Baltaş, 1986; Bozkurt, 2004). Spielberger'in (1966) kayg1 kuramına göre, durumluk ve sürekli kaygı olmak üzere iki faktörden oluşmaktadır (Duman, 2008). Durumluk kaygı bireyin yaşamında karşılaştı̆̆ durumlara ilişkin hissettiği öznel korku haliyken; sürekli kaygı ise karşılaştığı durumları çoğunlukla stresli bir biçimde algılama ve kaygı hissetmeye olan kişiliğe ilişkin bir eğilimdir (Öner ve Le Compte, 1985). 
Durumluk-sürekli kaygı ile ilgili yapılan bir çalışmada ikinci sınıf öğrencilerinin sürekli kaygılarının dördüncü sınıflara göre anlamlı bir şekilde daha yüksek olduğu sonucuna varılmıştır (Öztürk, 2008). Bu araştırmadan hareketle özellikle üniversitenin ilk yıllarında zorlu durumlarla baş etmekte güçlük çektikleri söylenebilir. Başka bir çalışmada öğrencilerin depresyonla durumluk-sürekli kaygıları arasında ilişki bulunmuştur (Şahin-Baltacı vd., 2020). Benzer şekilde üniversite öğrencilerinin durumluk-sürekli kaygı düzeyleri ile psikolojik belirtileri arasında pozitif yönde anlamlı bir ilişki bulunmuştur Özdemir'in (2013). Kaygı ile ilgili bir başka yaşantıda sosyal kaygıdır. İnsan sosyal bir varlık olmakla beraber hayatın önemli bir alanını kaplayan kişilerarası ilişkiler konusunda sosyal kaygı bireylerde olumsuz ve engelleyici bir etki yaratmaktadır (Kashdan, 2007). Üniversite öğrencilerinin yakınlık, ilişki kurma ihtiyaçlarını sosyal kaygı nedeniyle karşılayamıyor olmaları yaşamlarındaki işlevselliği etkilemekte, bunun yanı sıra birçok psikolojik probleme neden olabilmektedir. Nitekim ilgili araştırmalar incelendiğinde benzer sonuçlara ulaşılmaktadır (Kermen, Tosun ve Doğan, 2016; Gökkaya, 2016; Şahin-Baltacı vd., 2020). Özetle durumluk-sürekli kaygının ve sosyal kaygının üniversite öğrencilerinin işlevselliğini bozduğu görülmektedir.

Yukarıdaki bilgiler ışığında üniversite öğrencilerinin yeni yaşantılara maruz kaldıkları bu geçiş döneminde birçok psikolojik problem yaşamaktadır. Önleyici müdahalelerin de yeterli düzeyde olmaması öğrencilerin hem akademik başarısızlık hem de depresyon, intihar vb. gibi uzun dönemli olumsuz sonuçlar açısından risk grubuna yerleştirmektedir (Mortier vd., 2015). Bu noktada müdahale çalışmalarının artırılması bir psikiyatrik tanısı olan ve olmayan öğrenciler için intihar riski ve akademik başarısızlığa karşı koruyucu niteliktedir (Keyes vd., 2012). Bütün bunlar değerlendirildiğinde ruh sağlığını artırıcı müdahalelerin intihar riskini azaltacağı söylenebilir. Beliren yetişkinlik döneminde yaşanan psikolojik sıkıntıların bir halk sağlığı problemi olarak ele alınması gerektiğini vurgulayan Hunt ve Eisenberg (2010), kampüs içerisinde koruyucu ve önleyici müdahalelerin artması gerektiğinin altını çizmektedir. Akıl sağlı̆̆1 sorunlarının üniversite döneminde tedavi edilmesinin uzun vadede büyük ekonomik getirileri olduğu görülmektedir (Eisenberg vd., 2007). Akademik başarısızlık riski taşıyan öğrencilerin mezuniyet sonrası 
çalışma ortamında düşük verimliliğe yol açabileceği düşünülmektedir. Verimlilik ister akademide ister işyerinde olsun akıl sağlığının bir fonksiyonu olarak görülmektedir. Eğer akıl sağlığı ile verimlilik arasında nedensel bir ilişki varsa, toplum olarak akıl sağlığını koruyucu ve akıl hastalıklarını önleyici müdahaleler geliştiren ve uygulayan birimlerin kamusal anlamda desteklenmesi, fon oluşturulması gerektiği ortadadır. $\mathrm{Bu}$ sebeple üniversite kampüslerinde yer alan psikolojik danışma merkezlerinin insan sermayesi göz önüne alındığında uzun dönemli çok önemli ekonomik faydalar sağladıkları da söylenebilir.

Üniversite öğrencilerine müdahale çalışmalarının gerçekleştirilebilmesi için öncelikle öğrencilerin ihtiyaçlarını fark ederek yardım arama davranışında bulunmaları gerekmektedir. Akıl sağlığı problemlerini çevreleyen "sessizlik" kampüs iklimine de nüfuz eder ve üniversite öğrencilerinin yardım arama davranışlarını, psikolojik destek alma eğilimlerini, iyileşme süreçlerini ve psikolojik iyi oluş düzeylerini etkilemektedir (Wynaden vd., 2014). Üniversite dönemine geçen öğrenciler arasında tipik üniversiteye geçiş zorluklarını yönetmenin yanı sıra akıl sağlığını ilgilendiren zorluklarla mücadele eden öğrenci sayısının arttığı görülmektedir. Akıl sağlığını ilgilendiren zorluklara yönelik damgalanma sebebiyle, bu zorluklar gerçekte olduğundan daha düşük rapor edilmekte, öğrenciler bu zorlukların varlığını kabul edememekte ve destek aramamaktadır (Deges-White ve Borzumato-Gainey, 2014). Üniversite öğrencisi, ailesinden ve arkadaşlarından depresyonla ilgili damgalanmaya veya ayrımcılığa maruz kaldığında, üniversite psikolojik danışma merkezine başvurma veya depresyonun tedavisine ilişkin alternatif tedavileri arayıp bulma eğilimi azalmaktadır.

Bütün bunlar birlikte düşünüldüğünde yükseköğrenim kurumlarının bilimsel yöntemi benimsemelerinden dolayı en etkili müdahaleleri geliştirmek, uygulamak ve etkililiğini değerlendirmek için elverişli bir konumdadır. Üniversitenin işlevinin öğrencilerin akademik, fiziksel, bilişsel, sosyal ve duygusal yönlerden bir bütün olarak gelişmelerine katkıda bulunmak olduğu göz önüne alındığında, üniversite öğrencilerine yönelik verilen psikolojik danışma ve rehberlik hizmetlerinin ve bu öğrenci grubunun deneyimlerinin daha iyi kavranmasına yönelik araştırmaların önemi daha iyi anlaşılmaktadır (Şahin Baltacı ve Küçüker, 2017). Bu çalışmada bir devlet üniversitesinin Psikolojik Danışma ve Rehberlik Eği- 
tim Uygulama ve Araştırma Merkezine (PDREM) başvuran üniversite öğrencilerinin depresyon, sosyal kaygı, durumluk ve sürekli kaygı düzeylerinin ve intihar düşüncelerinin olup olmaması, psikiyatrik tanı alıp almama ve sinıf düzeylerine göre farklılık göstermekte midir? sorununa cevap aranacaktır. Bu araştırma sorusu doğrultusunda cevabı aranan alt problemler şunladır:

1. PDREM'e başvuran öğrencilerin depresyon, sosyal kaygı, durumluk ve sürekli kaygı düzeyleri cinsiyetlerine göre anlamlı bir farkll1ık göstermekte midir?

2. PDREM'e başvuran öğrencilerin depresyon, sosyal kaygı, durumluk ve sürekli kaygı düzeyleri intihar düşüncelerinin olup olmamasına göre anlamlı bir farklılık göstermekte midir?

3. PDREM'e başvuran öğrencilerin depresyon, sosyal kaygı, durumluk ve sürekli kaygı düzeyleri daha önce psikiyatrik tanı alıp almamalarına göre anlamlı bir farklılık göstermekte midir?

4. PDREM'e başvuran öğrencilerin depresyon, sosyal kaygı, durumluk ve sürekli kaygı düzeyleri sınıf düzeylerine göre anlamlı bir farklılık göstermekte midir?

\section{Yöntem}

\section{Araştırma Grubu}

$\mathrm{Bu}$ araştırmanın, araştırma grubunu 341'i kadın (\%77.7) ve 98'i (\%22.3) erkek olmak üzere PDREM'e başvuran toplam 439 üniversite öğrencisi oluşturmaktadır. Katılımcılar 19 farklı fakülte, yüksekokul, meslek yüksekokulunun 69 farklı bölümünde öğrenim görmekte olup \%2.5'i hazırlık, \%19.4'ü birinci sinıf, \%21.3'ü ikinci sınıf, \%28.7'si üçüncü sınıf, \%25.7'si dördüncü sınıf, \%2.0'si ise lisansüstü eğitimine devam etmektedir. Araştırma grubunda yer alan öğrencilerin \%21.4'ünde intihar düşünceleri bulunmaktadır. PDREM' e başvuran öğrencilerin tanılara göre dağılımı ise Tablo 1'de gösterilmiştir. 
Tablo 1. Psikolojik Danışma Merkezine Başvuran ve Psikiyatrik Tanı Alan Üniversite Öğrencilerinin Psikiyatrik Tanılarının Dă̆ılımı

\begin{tabular}{ll}
\hline Psikiyatrik Tanı & $\%$ \\
\hline Depresyon & 49.79 \\
Kaygı Bozukluğu & 35.26 \\
Obsesif Kompülsif Bozukluk (OKB) & 14.74 \\
Dikkat Eksikliği Hiperaktivite Bozukluğu (DEHB) & 7.69 \\
Bipolar Bozukluk & 5.13 \\
Sosyal Kaygı Bozukluğu & 3.84 \\
Borderline Kişilik Bozukluğu & 1.92 \\
Psikotik Bozukluk & 1.92 \\
Paranoid Bozukluk & 1.28 \\
\hline
\end{tabular}

Tablo 1 incelendiğinde, klinik tanıların depresyon \%46.79; kaygı bozukluğu \%35.26; obsesif kompülsif bozukluk (OKB) \%14.74; dikkat eksikliği hiperaktivite bozukluğu (DEHB) \%7.69; bipolar bozukluk \%5.13; sosyal kaygı bozukluğu \%3.84; borderline kişilik bozukluğu \%1.92; psikotik bozukluk \%1.92 ve paranoid bozukluk \%1.28 oranında bir dağılım sergilediği görülmektedir.

\section{Veri Toplama Araçları}

Veri toplama araçları olarak Başvuru Formu, Beck Depresyon Envanteri, Liebowitz Sosyal Fobi Ölçeği, Durumluk ve Sürekli Kaygı Ölçeği kullanılmıştır.

Beck Depresyon Ölçeği; Beck, Mendelson, Mock ve Erbaugh (1961) tarafından depresyonda görülen bedensel, duygusal, bilişsel ve motivasyonel belirtilerin şiddetini ölçmek amacıyla öz-değerlendirme niteliğinde geliştirilen bir ölçektir (Beck vd., 1961; Akt. Hisli, 1989). Ölçeğin toplamda yirmi bir belirti kategorisini vardır. Her maddede 4 seçenek vardır ve 0-3 arasında puan alır. Bu puanların toplanmasıyla depresyon puanı elde edilir. Ölçekten alınan puanlar 0 ile 63 arasında değişebilmekte ve alınan puanın yükselmesi depresyon düzeyinin şiddetlendiği anlamına gelmektedir. Ülkemizde geçerlilik ve güvenirlik çalışması Tegin ve Hisli tarafından yapılmıştır (Tegin, 1980; Hisli, 1989) ve ölçeğin alpha güvenirliğinin .80 olduğu ortaya konmuştur.]Üniversite öğrencilerinde yapılan uyarlama çalışmasında kesme puanları incelenerek 17 ve üzerindeki 
puanların depresyonu \%90'ın üzerinde bir doğrulukla ayırt edebildiği görülmüş̧ür (Hisli, 1989).

Sürekli-Durumluk Kaygı Envanteri; Spielberger ve arkadaşları tarafından bireylerin durumluk ve sürekli kaygı düzeylerini belirlemeyi amacıyla 1964 yılında geliştirilmiştir ve Türkçeye çevrilmesi, güvenirlik ve geçerlik çalışmaları Öner ve Le Compte (1983) tarafından yapılmıştır. Ölçek kendini değerlendirme türünde bir ölçektir ve kısa ifadelerden oluşan toplamda 40 maddeyi içermektedir. Ölçek, anlık olarak hissedilenleri belirlemek amacıyla 20 maddelik "durumluk kaygı formu" ve son yedi gündür hissedilenleri belirlemek amaciyla yine 20 maddelik "sürekli kaygı formu" olmak üzere iki kısımdan oluşmaktadır. 4'lü Likert tipi olan ölçeğin Cronbach Alpha güvenirliğinin .83 ile .87 arasında, testtekrar test güvenirliğinin .71 ile .86 arasında ve madde güvenirliğinin .34 ile .72 arasında değiştiği bildirilmektedir (Öner ve Le Compte 1998; Aydemir ve Köroğlu, 2000; Şahin, Batıgün ve Uğurtaş, 2002).

Liebowitz Sosyal Anksiyete Ölçeği; Liebowitz (1987) tarafından sosyal fobisi bulunan insanların zorluk yaşadığı çeşitli sosyal durumları değerlendirmek üzere geliştirilmiştir (Soykan, Özgüven ve Gençöz, 2003). Ölçekte bulunan her madde "korku veya kaygı" ve "kaçınma davranışı" için ayrı ayrı derecelendirilmiştir. Ölçek, Korku veya Kaygı ve Kaçınma için iki alt ölçek puanı ve toplam ölçek puanı vermektedir. Ölçeğin iç tutarlılığı oldukça yüksek olup Cronbach Alpha katsayısı .81 ile .92 arasinda değişmektedir (Heimberg, Horner, Juster, Safren, Brown, Scheier and Liebowitz, 1999). Ölçeğin Türkçe versiyonun test-tekrar test güvenirliği .97, Cronbach Alpha katsayıları ise Korku veya Kayg1 alt ölçekleri için .96; Kaçınma alt ölçeği için .95, tüm ölçek için ise 98 olarak belirlenmiştir (Soykan, Özgüven ve Gençöz, 2003).

\section{İşlem}

Ölçek formları, 2019-2020 Eğitim Öğretim yılında Pamukkale Üniversitesi öğrencileri tarafından psikolojik danışma merkezi sekreterliğinde bireysel ve gönüllü olarak doldurulmaktadır. Merkezden hizmet almak için başvuran öğrencilere verilen başvuru formlarının içerisinde yer alan 
ölçeklerden elde edilen verilerin bilimsel araştırmalarda kullanılabileceğine yönelik bilgilendirilmiş onay formu verilmiştir. Bu çalışma, Pamukkale Üniversitesi Sosyal ve Beşeri Bilimler Etik Kurulu tarafından onaylanmıştır (23.12.2020; 12-6).

\section{Verilerin Analizi}

Ölçeklerden elde edilen veriler SPSS 23 paket programı kullanılarak analiz edilmiştir. Verilerin analizinde aritmetik ortalama standart sapma, frekans ve yüzde gibi betimsel istatistiklerin yanı sıra, bağımsız iki grup arasındaki farkı test etmek için t-testi ve ikiden fazla grup arasındaki farkı test etmek için tek yönlü varyans analizi (ANOVA) kullanılmıştır. Verilerin parametrik istatistik sayıltılarını karşılayıp karşılamadığı incelenmiş bunun için, z standart puanı hesaplanarak uç değer incelemesi yapılmış ancak uçta kalan değere rastlanılmamıştır. Verilerin normal dağılım sayıltısı basıklık ve çarpıklık katsayısı ile incelenmiştir. Basıklık ve çarpıklık değerleri \pm 1 ve \pm 1 aralıklarında olduğu görülmüş buna göre, verilerin normal dağılım gösterdiği kanaatine varılmıştır (Büyüköztürk, 2012).

\section{Bulgular}

Araştırmada ele alınan problemler doğrultusunda verilerin analizinden elde edilen bulgular sırasıyla aşağıda sunulmuştur. Araştırmanın birinci alt problemi olan PDREM' e başvuran cinsiyetlerine göre depresyon, sosyal kaygı, durumluk kaygı ve sürekli kaygı düzeylerinin farklılaşıp farklılaşmadığına ilişkin t-testi yapılmış ve elde edilen bulgular Tablo 2 ' de verilmiştir.

Tablo 2. Cinsiyet Değişkenine Göre t-testi Sonuçları

\begin{tabular}{llllllllll}
\hline \multicolumn{1}{c}{ Kadın } & \multicolumn{9}{c}{ Erkek } \\
\hline & $\mathrm{X}$ & Ss & $\mathrm{X}$ & Ss & $\mathrm{X}$ & Ss & $t$ & $p$ & $d$ \\
\hline Depresyon & 20.87 & 10.224 & 19.34 & 11.397 & 20.53 & 10.503 & 1.275 & .203 & .014 \\
Sosyal Kayg1 & 96.38 & 26.821 & 93.21 & 27.457 & 95.67 & 26.965 & 1.024 & .306 & .011 \\
$\begin{array}{l}\text { Durumluk } \\
\text { Kayg1 }\end{array}$ & 47.63 & 11.264 & 45.17 & 11.105 & 47.08 & 11.263 & 1.906 & .057 & .021 \\
Sürekli Kayg1 & & & & & & & & & \\
\hline
\end{tabular}

$p<.05$ 
Tablo 2'ye göre, kadınların depresyon puan ortalamaları ( $\bar{x}=20.87$, $\mathrm{ss}=10.22)$ ile erkeklerin depresyon puan ortalamaları $(\bar{x}=19.34$, ss=11.39) anlamlı olarak farklılaşmamaktadır $(\bar{x}=20.53, \mathrm{p}>.05)$. Kadınların sosyal kayg1 puan ortalamaları $(\bar{x}=96.38, \mathrm{ss}=26.82)$ da erkeklerin sosyal kayg1 puan ortalamalarından ( $\bar{x}=93.21$, ss=27.45) anlamlı olarak farklılık göstermemektedir ( $\bar{x}=95.67, \mathrm{p}>.05)$. Durumluk kaygı puanlarının da kadınlar $(\bar{x}=47.63$, ss $=11.26)$ ve erkekler $(\bar{x}=45.17$, ss=11.10)arasında anlamlı şekilde farklılaşmadığı görülmektedir $(\bar{x}=47.08, \mathrm{p}>.05)$. Sürekli kayg1 puanları ise iki grup arasında farklılaşmaktadır. Buna göre kadınların sürekli kaygı puanları ( $\bar{x}=54.58, \quad s s=9.75)$ erkeklerin sürekli kayg1 puanlarından $(\bar{x}=50.25$, ss=10.01) anlamlı bir şekilde daha yüksektir $(\bar{x}=53.62, \mathrm{p}<.05)$. Cinsiyet değişkeni açısından grupların etki büyüklüklerini karşılaştırmak amacıyla Cohen etki büyüklüğü testi de yapılmıştır. Buna göre kadınlar ve erkekler arasında bağımlı değişkenler olan depresyon $(\mathrm{d}=.014)$, sosyal kayg1 $(\mathrm{d}=.011)$, durumluk kayg1 $(=.021)$ ve sürekli kayg1 $(\mathrm{d}=.043)$ puanları açısından etki büyüklükleri 0.2 'nin altında olduğu için zayıf olduğu söylenebilir (Cohen, 1988).

Araştırmanın ikinci alt problemi olan PDREM'e başvuran öğrencilerin intihar düşüncelerinin olup olmamasına göre depresyon, sosyal kayg1, durumluk kaygı ve sürekli kaygı düzeylerinin anlamlı olarak farklılaşıp farklılaşmadığına ilişkin $\mathrm{t}$ testi yapılmış ve elde edilen bulgular Tablo 3 'te verilmiştir.

Tablo 3. Intihar Düşüncesine Göre t-testi Sonuçları

\begin{tabular}{lllllllll}
\hline & $\begin{array}{l}\text { Intihar } \\
\text { Düşüncesi }\end{array}$ & $\mathbf{n}$ & $\mathbf{x}$ & $\begin{array}{l}\text { Standart } \\
\text { Sapma }\end{array}$ & $\mathbf{t}$ & sd & $\mathbf{p}$ & $\mathbf{d}$ \\
\hline Depresyon & Yok & 345 & 17.93 & 8.617 & -11.586 & 437 & .000 & .125 \\
& Var & 94 & 30.28 & 10.922 & & & & \\
\hline \multirow{2}{*}{ Sosyal Kayg1 } & Yok & 345 & 92.15 & 24.968 & -5.419 & 437 & .000 & .059 \\
& Var & 94 & 108.61 & 29.927 & & & & \\
\hline Durumluk Kayg1 & Yok & 345 & 45.23 & 10.548 & -6.938 & 437 & .000 & .079 \\
& Var & 94 & 53.85 & 11.138 & & & & \\
\hline Sürekli Kayg1 & Yok & 345 & 52.19 & 9.548 & -6.056 & 437 & .000 & .070 \\
& Var & 94 & 58.90 & 9.453 & & & & \\
\hline
\end{tabular}

$p<.05$

Tablo 2'ye göre, intihar düşüncesi olmayan grup $(\bar{x}=17.93$, ss=8.62) ile intihar düşüncesi olan grubun $(\bar{x}=30.28$, ss=10.92) depresyon puan orta- 
lamaları, olmayanların lehine anlamlı olarak farklılaşmaktadır (t (437) =11.586, $\mathrm{p}<001)$. İntihar düşüncesi olmayan grup $(\bar{x}=92.15$, ss=25.00) ile intihar düşüncesi olan grubun ( $\bar{x}=108.61$, ss=29.93) sosyal kayg1 puan ortalamaları intihar düşüncesi olmayanların lehine anlamlı olarak farkl1lik göstermektedir ( $\mathrm{t}(437)=-5.419, \mathrm{p}<.001)$. Benzer şekilde, intihar düşüncesi olmayan grup ( $\bar{x}=45.23$, ss=10.55) ile intihar düşüncesi olan grubun $(\bar{x}=53.85$, ss=11.14) durumluk kayg1 puan ortalamaları intihar düşüncesi olmayanların lehine anlamlı olarak farklılık göstermektedir. ( $\mathrm{t}(437)=-$ $6.938, \mathrm{p}<.001)$. Son olarak intihar düşüncesi olmayan grup $(\bar{x}=52.19$, ss=9.48) ile intihar düşüncesi olan grubun $(\bar{x}=58.90$, ss=9.45) sürekli kayg1 puan ortalamaları intihar düşüncesi olmayanlar lehine anlamlı olarak farklılaşmaktadır (t (437) =-6.056, p<.001). İntihar düşüncesi açısından grupların etki büyüklüklerini karşılaştırmak amacıyla Cohen etki büyüklüğü testi de yapılmıştır. Buna göre intihar düşüncesinde depresyon (d=.125), sosyal kaygı (d=.059), durumluk kaygı (=.079) ve sürekli kaygı $(\mathrm{d}=.070)$ puanları açısından etki büyüklükleri $0.2^{\prime}$ nin altında olduğu için zayif olduğu söylenebilir (Cohen, 1988).

Araştırmanın üçüncü alt problemi olan PDREM'e başvuran öğrencilerin tanı alıp almamalarına göre depresyon, sosyal kaygı, durumluk kaygı ve sürekli kaygı düzeylerinin anlamlı olarak farklılaşıp farklılaşmadığına ilişkin $\mathrm{t}$ testi yapılmış ve elde edilen bulgular Tablo 4 'te verilmiştir.

Tablo 4. Psikiyatrik Tanı Alma Durumuna Göre t-testi Sonuçları

\begin{tabular}{lllllllll}
\hline & $\begin{array}{l}\text { Psikiyatrik } \\
\text { Tanı }\end{array}$ & $\mathbf{n}$ & $\bar{x}$ & $\begin{array}{l}\text { Standart } \\
\text { Sapma }\end{array}$ & $\mathbf{T}$ & Sd & $\mathbf{p}$ & $\mathbf{d}$ \\
\hline Depresyon & Yok & 283 & 18.24 & 9.209 & -6.615 & 437 & .000 & .064 \\
& Var & 156 & 24.82 & 11.251 & & & & .039 \\
\hline Sosyal Kayg1 & Yok & 283 & 91.88 & 24.360 & -4.042 & 437 & .000 & .039 \\
& Var & 156 & 102.55 & 29.942 & & & & \\
\hline Durumluk Kayg1 & Yok & 283 & 45.13 & 11.017 & -5.022 & 437 & .000 & .050 \\
& Var & 156 & 50.61 & 10.794 & & & & .000 \\
\hline Sürekli Kayg1 & Yok & 283 & 51.78 & 9.577 & -5.409 & 437 & .053 \\
& Var & 156 & 56.97 & 9.652 & & & & \\
\hline
\end{tabular}

$p<.05$

Tablo 4 incelendiğinde, psikiyatrik tanısı olmayan grup ( $\bar{x}=18.24$, $\mathrm{ss}=9.21)$ ile psikiyatrik tanisı olan grubun $\bar{x}=24.82$, $\mathrm{ss}=11.25$ ) depresyon puan ortalamaları psikiyatrik tanısı olmayanların lehine anlamlı olarak 
farkl1l1k göstermektedir $\left(\mathrm{t}_{(437)}=-6.615, \mathrm{p}<.001\right)$. Benzer şekilde, psikiyatrik tanisı olmayan grup $(\bar{x}=91.88, \mathrm{ss}=24.36)$ ile psikiyatrik tanısı olan grubun $(\bar{x}=102.55$, ss $=29.94)$ sosyal kaygı puan ortalamaları arasında psikiyatrik tanısı olmayanların lehine anlamlı farklılık görülmektedir $\left(\mathrm{t}_{(437)}=-4.042\right.$, $\mathrm{p}<.001)$. Buna ek olarak, psikiyatrik tanisı olmayan grup $(\bar{x}=45.13$, ss=11.02) ile psikiyatrik tanısı olan grubun (V50.61, ss=10.79) durumluk kaygı puan ortalamaları psikiyatrik tanısı olmayanların lehine anlamlı olarak farklılaşmaktadır $\left(\mathrm{t}_{(437)}=-5.022, \mathrm{p}=.001\right)$. Son olarak psikiyatrik tanısı olmayan grup ( $\bar{x}=51.78$, ss $=9.58)$ ile psikiyatrik tanısı olan grubun $\bar{x}=56.97$, ss=9.65) sürekli kaygı puan ortalamaları psikiyatrik tanısı olma-

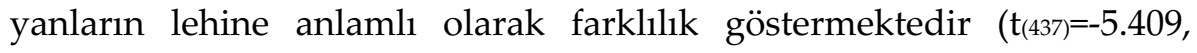
$\mathrm{p}<.001)$. Etki büyüklükleri açısından ise depresyon ( $\mathrm{d}=.064)$, sosyal kayg1 $(\mathrm{d}=.039)$, durumluk kayg1 (=.050) ve sürekli kaygının ( $\mathrm{d}=.053)$ 0.2' nin altında olduğu için zayıf etki büyüklüğünde olduğu söylenebilir (Cohen, 1988).

Araştırmanın dördünce ve son alt problemi olan PDREM' e başvuran öğrencilerin sınıf düzeylerine göre depresyon, sosyal kaygı, durumluk kaygı ve sürekli kaygı düzeylerinin anlamlı olarak farklılaşıp farklılaşmadığını ortaya koymak için ANOVA yapılmış ve elde edilen bulgular Tablo 5'te verilmiştir.

Tablo 5. Stnıf Düzeyine Göre ANOVA Sonuçları

\begin{tabular}{lllllllll}
\hline Değişken & $\begin{array}{l}\text { Sinıf } \\
\text { Düzeyi }\end{array}$ & $\mathbf{n}$ & $\bar{x}$ & SS & sd & F & $p$ & $d$ \\
\hline Depresyon & 1 & 79 & 21.57 & 10.469 & $3 / 387$ & 6.643 & .000 & .067 \\
& 2 & 87 & 24.07 & 12.345 & & & & \\
& 3 & 117 & 18.13 & 8.685 & & & & \\
& 4 & 105 & 18.95 & 9.863 & & & & \\
\hline Sosyal Kayg1 & 1 & 79 & 96.67 & 24.505 & $3 / 387$ & 3.110 & .026 & .026 \\
& 2 & 87 & 102.68 & 29.096 & & & & \\
& 3 & 117 & 93.61 & 24.657 & & & & \\
\hline Durumluk Kayg1 & 4 & 105 & 91.53 & 28.311 & & & & .031 \\
& 2 & 79 & 47.47 & 11.654 & $3 / 387$ & 3.808 & .010 & \\
& 3 & 87 & 49.84 & 10.638 & & & & \\
\hline Sürekli Kayg1 & 117 & 44.54 & 10.814 & & & & \\
& 4 & 105 & 47.10 & 11.651 & & & & \\
& 2 & 79 & 55.01 & 8.519 & $3 / 387$ & 2.792 & .040 & .028 \\
& 3 & 87 & 55.51 & 10.515 & & & & \\
& 4 & 117 & 52.44 & 8.536 & & & & \\
\hline
\end{tabular}

$p<.001, p<.05$ 
Tablo 5 incelendiğinde sinıf düzeylerine göre depresyon $(\mathrm{F}(387)$ $=6.643, \mathrm{p}<.001)$; sosyal kayg1 $(\mathrm{F}(387)=3.110, \mathrm{p}<.05)$; durumluk kayg1 $(\mathrm{F} 387=3.808, \mathrm{p}<.05)$ ve sürekli kayg1 puan ortalamalarının $(\mathrm{F}(387)=2.792$, $\mathrm{p}<.05)$ anlamlı olarak farklılaştığı görülmektedir. Anlamlı farkın hangi gruplar arasında olduğunu bulmak için Bonferroni testi yapılmıştır. Buna göre Tablo $5^{\prime}$ ten de izlenebileceği gibi depresyon düzeyleri incelendiğinde, 2-3. sinıf arasında 2. sinıf lehine, 2-4. sinıf arasında 2. sinıf lehine anlamlı fark vardır. Bir başka deyişle ikinci sınıf öğrencilerinin depresyon düzeyleri üçüncü ve dördüncü sinıf öğrencilerinin depresyon düzeylerine göre daha yüksektir. Sosyal kaygı düzeyleri incelendiğinde, 24. sinıflar arasında 2. sinıf lehine anlamlı fark bulunmaktadır. Durumluk kaygı düzeyleri incelendiğinde, 2-3. sinıf arasında 2. sınıf lehine anlamlı fark görülmektedir. Sürekli kaygı düzeyleri incelendiğinde gruplar arasında anlamlı bir farklılık görülmemektedir. Etki büyüklükleri açısından ise depresyon $(\mathrm{d}=.067)$, sosyal kayg1 $(\mathrm{d}=.026)$, durumluk kayg1 $(\mathrm{d}=.031)$ ve sürekli kaygı $(\mathrm{d}=.028)$ puanları zayıf etki büyüklüğündedir.

\section{Tartışma}

$\mathrm{Bu}$ araştırmada, elde edilen sonuçlar, cinsiyete göre katılımcıların depresyon, sosyal, durumluk kaygı arasında anlamlı bir fark bulunmazken, sürekli kaygı düzeylerinin kadınların erkeklere göre anlamlı olarak daha yüksek olduğunu göstermektedir. İntihar düşüncesine sahip olan kattlımcıların depresyon, sosyal, durumluk ve sürekli kaygı düzeylerinin bu düşünceye sahip olmayanlardan anlamlı olarak daha yüksek olduğunu göstermektedir. Ayrıca geçmişte psikiyatrik tanı almış katılımcların da depresyon, sosyal, durumluk ve sürekli kaygı düzeylerinin psikiyatrik tanı almamış olanlardan anlamlı olarak daha yüksek olduğu görülmüştür. Sınıf düzeylerine göre incelendiğinde ise birinci ve ikinci sınıf üniversite öğrencilerinin yüksek düzeyde depresyon, sosyal, durumluk ve sürekli kaygı deneyimlediği ortaya konmuştur.

Araştırmada yanıt aranan ilk problem, "PDREM'e başvuran öğrencilerin depresyon, sosyal kaygı, durumluk ve sürekli kaygı düzeyleri cinsiyetlerine göre anlamlı bir farklılık göstermekte midir?" şeklinde ifade edilmiştir. PDREM'e başvuran öğrencilerde cinsiyete göre fark buluna- 
mamıştır. Literatür incelendiğinde araştırmamıza benzer şekilde cinsiyetler arasında depresyon düzeylerinde farklılık görülmemektedir (Erözkan, 2005, Ulaş, 2015). Araştırmamıza paralel bir bulgu olarak durumluk kaygı ile cinsiyet arasında farklılık bulunmamıştır (Kaya ve Varol, 2004; Aydın ve Tiryaki, 2017). Literatür incelendiğinde farklı sonuçlara ulaşıldığı anlaşılmaktadır. Öğrencilerin kaygı düzeylerinin incelendiği bazı çalışmalarda cinsiyete göre farklılık olduğu bulgusuna ulaşılırken (Kula ve Saraç, 2016; Deveci vd., 2012, Gündoğdu vd., 2011); bazı çalışmalarda da cinsiyetin kaygı ile anlamlı bir farklılık ilişkisi olmadığ sonuçlarına ulaşılmıştır (Dursun ve Aytaç, 2009; Tektaş, 2014). Literatürde farklı sonuçlara ulaşılmış olsa da mevcut araştırmada elde edilen sonuç göz önüne alındığında; kadınların cinsiyete özgü biyolojik özelliklerin psikolojik rahatsızlıklara katkıda bulunduğu söylenebilir.

Araştırmada araştırdığımız sorulardan bir diğeri “PDREM'e başvuran öğrencilerin depresyon, sosyal kaygı, durumluk ve sürekli kaygı düzeyleri intihar düşüncelerinin olup olmamasına göre anlamlı bir farklılık göstermekte midir?" şeklindedir. İntihar düşünceleri ile birlikte depresyon, kaygının ele alındığı sınırlı sayıda çalışma vardır. Literatür incelendiğinde intihar düşüncesi ile depresyon negatif yönlü intihar düşüncesi vardır (Bildik vd., 2013; Westefeld vd., 2015) ve kaygı arasında negatif yönlü ilişkiler vardır (Westefeld vd., 2015). Mevcut araştırmadaki değişkenlerin bireylerin yaşamında işlevselliği bozduğu yaşam kalitesini düşürdüğü yetersiz hissettikleri (Ünal vd., 2010) göz önüne alındığında bu bireylerin yalnızlaştıkları ve bu problemlere sahip olmaları nedeniyle baş etme mekanizmalarının yetersiz intihar düşüncelerine daha eğilimli oldukları söylenebilir.

Araştırmada üçüncü yanıt aranan problem de "PDREM'e başvuran öğrencilerin depresyon, sosyal kaygı, durumluk ve sürekli kaygı düzeyleri daha önce psikiyatrik tanı alıp almamalarına göre anlamlı bir farklılık göstermekte midir?" sorusudur. Ulaşılabilen literatürde önceden tanı almış olmakla depresyon, sosyal kaygı, durumluk ve sürekli kaygı düzeyleri ile ilişkili bir çalışmaya rastlanmamıştır. Ancak tanı almış üniversite öğrencilerinin toplum içerisinde yetersizlik ve çaresizlik yaşadıkları ve dışlanacaklarına ilişkin bir inançları olduğu görülmektedir (Ünal vd., 2010). Avcil, Bulut ve Sayar ‘a (2016) göre kendi kendini damgalayan ya da içselleştirilmiş damgalanma bireyin kendini, sürecini ve iyileşmeye 
yönelik tepkilerini aksatmakta ve utanç, değersizlik gibi duygularla toplumdan geri çekilmelerine, iyileşmeye yönelik adım atmamalarına neden olmaktadır. Türkiye Psikiyatri Derneği'nin 2007 yılında gerçekleştirilen çalışmasında; hastaların \%46'sının kendilerini tam veya kısmen yetersiz ya da eksik görürken, yaklaşık \%40 da çevresindeki kişilerce tam veya kısmen yetersiz ya da eksik algılandıklarını ifade etmişlerdir (Ersoy ve Varan, 2005). Bir diğer çalışmada benzer şekilde damgalanma algısına sahip olan bireylerin daha az ilişki kuruduğunu göstermektedir (Camp vd., 2002). Tanı almak toplumdan uzaklaşmalarına, değersizlik ve yetersizlik duygularını yoğun bir şekilde yaşamalarına neden olduğu anlaşılmaktadır. Buradan hareketle bu bireylerin yaşam kalitesinin düştüğü ve halihazırdaki inançları nedeniyle iyileşme süreçlerinin geciktiği ya da iyileşmeye yönelik adım atmakta çekindikleri görülmektedir. Bu çalışmalar göz önüne alındığında tanı almış ve iyileşmemiş olan bu bireylerin tekrar yardım arayışları olsa dahi rahatsızlıkları devam ettiği için mevcut araştırmada ulaşıldığı gibi tanı almamış bireylere kıyasla depresyon, sosyal kayg1, durumluk ve sürekli kaygılarının daha yüksektir.

Araştırmada yanıt aranan son problem de "PDREM'e başvuran öğrencilerin depresyon, sosyal kaygı, durumluk ve sürekli kaygı düzeyleri sinıf düzeylerine göre anlamlı bir farklılık göstermekte midir?" sorusudur. Üniversite kampüsü gibi mikrososyal ortamların küçük akademik gruplarda sosyal rollerin belirlenmesi, ailevi/sınıf içi çatışmalar, akran ilişkilerinde sorunlar, akademik personel ile iletişim sorunları, oda arkadaşıyla yaşanan sıkıntılar gibi zorlukları bulunmakla beraber gelişim döneminin benlik gelişimine, varoluşsal sorgulamalara ve rekabetçi sosyal ortama ilişkin sorunlar ile birleştiğinde kendine has bir dönem olduğu görülmektedir (Kulygina, 2015). Olası stres faktörleri arasında lise arkadaşlıklarının kaybı, yeni ilişkiler kurma gerekliliği, evden uzakta kalma, oda arkadaşıyla yaşama, farklı öğrenme yöntemlerine alışma, yaşamda ve akademik alanda artan özerklik beklentisi sayılabilir (Cleary vd., 2010). Bütün bunlarla birlikte mevcut araştırmada ikinci sınıf üniversite öğrencilerinin birinci, üçüncü ve dördüncü sınıf öğrencilerden daha yüksek depresyon ve kaygı seviyelerine sahip olduğu görülmüştür. İlgili literatür incelendiğinde birinci sınıfların geçiş döneminin doğası gereği birçok zorluk yaşadığı görülmektedir, mevcut araştırmanın sonuçlarıyla birlikte birinci sınıf öğrencilerinin yardım arama davranışları- 
nın gelecekteki çalışmalarda daha detaylı incelenmesi gerektiği düşünülmektedir. Bu bulguda birinci sınıf öğrencilerinin yeni bir gelişim dönemine adım atmaları, yeni bir sosyal çevreye dahil olmaları ve akademik sorumlulukları ile baş etmek için üniversite kaynakları yerine var olan sosyal destek kaynaklarını kullandıkları, hala geçmişteki sosyal destek bağlarının devam ettiği ve bu faktörler aracılığıyla yardım arama davranışının ilk yıl değil, ikinci yıl ortaya çıkmış olabileceği düşünülmektedir.

\section{Sonuç}

Psikolojik danışma merkezine başvuran üniversite öğrencilerinin büyük çoğunluğu orta düzey depresyon, sosyal kaygı, durumluk ve sürekli kayg1 düzeyine sahiptir. İntihar düşüncesine sahip olan öğrencilerin depresyon, sosyal kaygı, durumluk ve sürekli kaygı düzeyleri bu düşünceye sahip olmayanlara göre daha yüksektir. Geçmişte psikiyatrik tanı almış üniversite öğrencilerinin depresyon, sosyal kaygı, durumluk ve sürekli kaygı düzeyleri böyle bir tanı almayanlara göre daha yüksektir. Üniversite birinci ve ikinci sinıflar depresyon, sosyal kaygı, durumluk ve sürekli kaygı için risk grubudur. Önleyici müdahaleler kapsamında birinci ve ikinci sınıf öğrencilerinin genel taramalardan düzenli olarak geçirilmesi, gerektiğinde psikiyatriye yönlendirmelerin yapılmasının ilerleyen sınıf düzeylerinde ve meslek hayatlarında depresyon ve kaygı ile başa çıkmada gereken becerileri kazanmalarına yardımcı olacağı düşünülmektedir. Öte yandan, yükseköğrenimin ilk iki senesinde yeterli psikolojik danışmanlık hizmetinden yararlanmayan öğrenciler, daha sonraki sene yaşadıkları sorunların katlanarak artması olasılığı da göz önünde bulundurularak psikolojik danışmanlık yerine psikiyatriye yönlendirilmek durumunda kalabilirler. Psikolojik danışma merkezlerine yapılan geç başvuruların ileriki araştırmalar tarafından derinlemesine incelenmesi gerekmektedir. Bu çerçeveden bakıldığında üniversitenin ilk yılında çevrimiçi ve yüz yüze gerçekleştirilecek oryantasyon programlarının gerçekleştirilmesi, uzaktan veya yüz yüze psikolojik danışmanlık hizmetlerinin artırılmasının, birinci sınıf üniversite öğrencilerinin psikolojik yardım aramaya yönelik tutumlarının daha derinlemesine incelenmesinin ve kampüs çapında psikolojik sağlığa yönelik taramaların ya- 
pılmasının önemi açıkça görülmektedir. Bu araştırmanın sınırlılıkları bulunmaktadır. Üniversite psikolojik danışma merkezine çeşitli sebeplerden başvurmayan öğrencilere ulaşılmamıştır. Araştırmanın verileri self-report ölçeklerden elde edilmiştir. Öğrencilerin içten ve samimi bir şekilde doldurduğu varsayılmıştır. Araştırma verileri bu araştırmaya katılan psikolojik danışma merkezine başvuran öğrenciler ile sınırlıdır. Diğer öğrenci gruplarına veya diğer üniversitelere genellenemeyebilir.

Araştırmacılara öneriler arasında, depresyon ve kaygı için risk grubunda olan üniversite öğrencilere yönelik önleyici müdahale programlarının etkililiğinin incelenmesi, geçmişte psikiyatrik tanı almış üniversite öğrencilerine yönelik gerçekleştirilen bireysel ve grup destek hizmetlerinin etkililiğinin incelenmesi verilebilir.

Uygulayıcılara yönelik öneriler şu şekilde sıralanabilir. Yükseköğrenimin birinci ve ikinci sınıflarında olan öğrenciler öncelikli hedef kitle olarak belirlenerek, psikolojik yardım aramaktan kaçınan öğrenciler ve ailelerine yönelik bilgilendirme çalışmaları yapılabilir. Öğrencilerin yaşadıkları zorlukların psikiyatrik müdahale gerektirecek boyuta gelmemesi adına koruyucu ve önleyici çalışmalar artırılabilir. İntihar riskinin belirlenmesine yönelik tarayıcı çalışmalar yapılabilir. Psikiyatrik tanı alan öğrencilere yönelik iyileştirici çalışmalar yapılabilir, öğrenciler takip sürecine dahil edilebilir. Kendine yardım broşürleri ve akran danışmanlığı, online oryantasyon programları, çevrimiçi psiko-eğitimler ve çevrimiçi psikolojik danışmanlık gibi hizmetlerle psikolojik danışma merkezlerinin etki alanı yaygınlaştırılabilir. Üniversite kampüslerinde yer alan spor merkezleri, sanat ve kültürel faaliyetler gösteren merkezler ve öğrenci toplulukları ile ortak çalışmalar yürütülmesi planlanabilir. Bütün bu önerilerin gerçekleştirilmesiyle birlikte yükseköğrenim gören öğrencilerin yaşantılarının ilk ve ikinci yıllarında yaşadıkları zorluklarla baş etmelerinde yardımcı olunabilir.

Öte yandan üniversite yönetimlerine öneriler şu şekildedir: Kampüsteki yoğun öğrenci popülasyonuna yeterli hizmet verecek psikolojik danışman sayısı artırılabilir. Psikolojik danışma merkezlerinin yapacağı bilgilendirme çalışmaları için gereken fonlar sağlanabilir. Psikolojik yardım almaya ihtiyacı olan öğrencilerin ilgili birime yönlendirilebilmesi için akademik ve idari personel bilgilendirilebilir. Üniversiteye bağlı psikiyatri servisleri ve acil servis poliklinikleri personelinin intihar dü- 
şünceleri ve girişimi gibi acil durumlarla ilgili izleyecekleri prosedürler netleştirilebilir. Psikolojik danışmanların öğrencilere daha etkin bir şekilde ulaşabilmesi amacıyla uzaktan erişim seçenekleri değerlendirilebilir, online psikolojik danışma için gerekli altyapı desteği sağlanabilir. 
EXTENDED ABSTRACT

\section{Investigation of Depression, Social Anxiety, State and Trait Anxiety Levels of College Students Appl- ying to Counseling Center According to Suicidal Thoughts and Psychiatric Diagnosis}

Hülya Şahin Baltacı- Deniz Küçüker-Uğur Yiğit Karataş-Işı Özkılıç-Hilal Asena Özdemir Pamukkale University

Universities represent higher education institutions where it is aimed to raise individuals who can be beneficial to society (Yeşilyaprak, 1985). In addition to being one of the important developmental periods when individuals encounter many new experiences, college years are a stressful time for most of the students and challenge their coping mechanisms. Young adults face many developmental changes and challenges such as separation from parents, establishing personal relationships, living independently, and discovering their own identity (D'Amico, Mechling, Kemppainen, Ahern, and Lee, 2016). When college life is considered as a transition period, while the adaptation process takes place quickly for some students, it may follow a more complex process that spreads to the first years of the university for other students. It is observed that depressive symptoms, which are usually characterized by stress, can progress, or intensify, especially in students who experience this process in a complex way (Lee, Dickson, Conley, and Holmbeck, 2014). In the light of the above information, university students experience many psychological problems during this transition period when they are exposed to new experiences. The insufficient level of preventive interventions places students in the risk group in terms of both academic failure and longterm negative consequences such as depression and suicide.

The aim of this study is to examine whether depression, social anxiety, state anxiety, and trait anxiety levels of college students who applied to a counseling center differ according to their suicidal thoughts, psychiatric diagnosis, and class standing. Research group consists of a total of 439 college students, 341 women and 98 men. Counseling Center Application Form, Beck Depression Inventory, Liebowitz Social Phobia Scale, and State and Trait Anxiety Scale were used as data collection tools in 
the study. This research was approved by Pamukkale University Social and Human Sciences Ethics Committee (23.12.2020; 12-6). To test the aims of the research, t-test, ANOVA, and descriptive statistics were used in data analysis. According to the findings, it was observed that $17.1 \%$ of the students had minimal depression, $21 \%$ had mild, $42.4 \%$ had moderate and $19.6 \%$ had severe depression; $1.8 \%$ had very low social anxiety, $23.5 \%$ had low, $40.2 \%$ had moderate, $23.5 \%$ had high and $10.9 \%$ had very high social anxiety; $32 \%$ had low state anxiety, $44.6 \%$ had moderate, $19.4 \%$ had high and $3.9 \%$ had very high state anxiety, $15.7 \%$ had low trait anxiety, $46.1 \%$ had moderate, $32.9 \%$ had high and $5.3 \%$ had very trait anxiety. It was found that $19.1 \%$ of the participants were referred to a psychiatric service, $21.4 \%$ had suicidal thoughts, $36 \%$ had a psychiatric diagnosis previously. In addition, it was revealed that those who have suicidal thoughts show a significant difference in favor of those who have suicidal thoughts when compared with those who do not have suicidal thoughts in terms of research variables. It was revealed that those who had a psychiatric diagnosis in the past showed a significant difference in terms of study variables in favor of those who had a psychiatric diagnosis compared to those who did not have a psychiatric diagnosis in the past. Finally, it was observed that depression, social anxiety, state, and trait anxiety levels differ significantly according to class standing.

When all these findings are evaluated together, it is revealed that most university students who applied to the psychological counseling center have moderate levels of depression, social anxiety, state, and trait anxiety. Depression, social anxiety, state, and trait anxiety levels of students who have suicidal ideation are higher than those who do not have this idea. Depression, social anxiety, state, and trait anxiety levels of university students who had a psychiatric diagnosis in the past were higher than those who did not have such diagnosis. University freshmen and sophomores are at risk for depression, social anxiety, state, and trait anxiety. It is thought that regular screening of first- and second-year students within the scope of preventive interventions and referring those who need psychiatric treatment, will help them acquire the skills necessary to cope with depression and anxiety in their later years at college and in their professional lives. 
When the relevant literature is examined, it is suggested that increasing the frequency and scope of intervention programs are protective against suicide risk and academic failure for students with and without a psychiatric diagnosis (Keyes et al., 2012). Moreover, it can be said that mental health-enhancing interventions will reduce the risk of suicide. Hunt and Eisenberg (2010), emphasizing that psychological problems experienced in emerging adulthood should be considered as a public health problem, underline the need to increase protective and preventive interventions within the campus. It appears that treating mental health problems during higher education has great economic benefits in the long run as well (Eisenberg et al., 2007). Because higher education institutions embrace the scientific method, they are in a favorable position to develop, implement and evaluate the effectiveness of the most effective interventions.

It is thought that students at risk of academic failure may lead to low productivity in the post-graduation work environment. Productivity is viewed as a function of mental health, whether in academia or the workplace. If there is a causal relationship between mental health and productivity, it is obvious that institutions that develop and implement preventive mental health interventions should be publicly supported and funded. For this reason, it can be said that psychological counseling centers located on university campuses provide very important long-term economic benefits when human capital is considered.

\section{Kaynakça/References}

Altemus, M., Sarvaiya, N. and Epperson, C. N. (2014). Sex differences in anxiety and depression clinical perspectives. Frontiers in Neuroendocrino$\log y, 35(3), 320-330$.

Aslan, A. E., Kalkan, N., Başman, M. ve Yaman, K. G. (2020). A Study for the Prediction of the Social Anxiety Level of University Students Through Emotional Intelligence Features. Türk Psikolojik Danışma ve Rehberlik Dergisi, 10(57), 201-228.

Avcll, C., Bulut, H. ve Sayar, G. H. (2016). Psikiyatrik hastalıklar ve damgalama. Üsküdar Üniversitesi Sosyal Bilimler Dergisi, 2, 175-202. 
Aydın, A. ve Tiryaki, S. (2017). Üniversite öğrencilerinin kaygı düzeylerini etkileyen faktörleri belirlemeye yönelik bir çalışma (KTÜ örneği). Kastamonu Univ. Orman Fakültesi Dergisi, 17(4), 715-722.

Ballaş, A. vd. (1986). Kaygı düzeyi açısından okullar arası farklar. XXII. Ulusal Psikiyatri ve Nörolojik Bilimler Kongresi, Marmaris.

Beiter, R., Nash, R., McCrady, M., Rhoades, D., Linscomb, M., Clarahan, M. and Sammut, S. (2015). The prevalence and correlates of depression, anxiety, and stress in a sample of college students. Journal of Affective Disorders, 173, 90-96.

Bildik, T., Somer, O., Kabukçu Başay, B., Başay, Ö., ve Özbaran, B. (2013). Kendine zarar verme davranışı değerlendirme envanterinin Türkçe formunun geçerlik ve güvenilirlik çalışması. Türk Psikiyatri Dergisi, 24(1), 4957.

Bozkurt, N. (2004). Bir grup üniversite öğrencisinin depresyon ve kaygı düzeyleri ile çeşitli değişkenler arasındaki ilişkiler. Ĕ̆itim ve Bilim, 29(133), 5259.

Bruffaerts, R., Mortier, P., Kiekens, G., Auerbach, R. P., Cuijpers, P., Demyttenaere, K. and Kessler, R. C. (2018). Mental health problems in college freshmen: Prevalence and academic functioning. Journal of Affective Disorders, 225, 97-103.

Bumberry, W., Oliver, J. M., and McClure, J. N. (1978). Validation of the Beck Depression Inventory in a university population using psychiatric estimate as the criterion. Journal of Consulting and Clinical Psychology, 46(1), 150.

Büyüköztürk, Ş. (2012). Sosyal bilimler için veri analiz el kitabı (17.Baskı). Ankara: Pegem Akademi.

Camp DL, Ginlay W. M. and Lyons E (2002). Is low self-esteem an inevitable consequence of stigma? An example from women with chronic mental health problems. Sos Sci Med, 55, 823-834.

Ceyhan, E. ve Ceyhan, A. A. (2011). Loneliness and depression levels of the students applying the university counseling center. Eğitim ve Bilim, $36(160), 81$.

Cleary, M., Horsfall, J. and Happell, B. (2010). Developing practice in mental health settings. International Journal of Mental Health Nursing, 19(1), 4552.

Cohen J. (1988). The analysis of variance. In statistical power analysis for the Behavioral Sciences (second ed.). 274-278. Lawrence Erlbaum Associates. 
Cook, L. J. (2007). Striving to help college students with mental health issues. Journal of Psychosocial Nursing and Mental Health Services, 45(4), 40-44.

Cukrowicz, K. C., Cheavens, J. S., Van Orden, K. A., Ragain, R. M. and Cook, R. L. (2011). Perceived burdensomeness and suicide ideation in older adults. Psychology and Aging, 26(2), 331-338.

D’Amico, N., Mechling, B., Kemppainen, J., Ahern, N. R. and Lee, J. (2016). American college students' views of depression and utilization of oncampus counseling services. Journal of the American Psychiatric Nurses Association, 22(4), 302-311.

Degges-White, S. and Borzumato-Gainey, C. (Eds.). (2013). College student mental health counseling: A developmental approach. New York: Springer Publishing Company.

Deniz, M.E., Avşaroğlu S. ve Hamarta, E. (2004). Psikolojik danışma servisine başvuran üniversite öğrencilerinin psikolojik belirti düzeylerinin incelenmesi. Selçuk Üniversitesi Ĕ̆itim Fakültesi Dergisi, 16-17-18, 139-152.

Deveci, S. E., Çalmaz, A. ve Açı, Y. (2012). Doğu Anadolu'da yeni açılan bir üniversitenin öğrencilerinde kaygı düzeylerinin sağlık, sosyal ve demografik faktörler ile ilişkisi. Dicle Tıp Dergisi, 39(2), 189-196.

Dursun S. ve Aytaç S. (2009). Üniversite öğrencileri arasında işsizlik kaygısı. Uludă̆ Üniversitesi İktisadi ve İdari Bilimler Fakültesi Dergisi, 28(1), 71-84.

Erözkan, A. (2005). Üniversite öğrencilerinin kişilerarası duyarlılık ve depresyon düzeylerinin bazı değişkenlere göre incelenmesi. Muğla Üniversitesi Sosyal Bilimler Enstitüsü Dergisi, 14, 129-155.

Eisenberg, D., Gollust, S. E., Golberstein, E. and Hefner, J. L. (2007). Prevalence and correlates of depression, anxiety, and suicidality among university students. American Journal of Orthopsychiatry, 77(4), 534-542.

Ersoy, M. A. ve Varan, A. (2007). Ruhsal hastalıklarda içselleştirilmiş damgalanma ölçeği, Türkçe Formu'nun güvenirlik ve geçerlik çalışması. Türk Psikiyatri Dergisi, 18(2), 163-171.

Gökkaya, M. (2016). Bir grup üniversite öğrencisinde sosyal kaygl, depresyon ve annebaba tutumları ile mükemmeliyetçilik eğilimleri ve üniversiteye uyum arasındaki ilişkinin değerlendirilmesi. (Master's thesis). Işık Üniversitesi Sosyal Bilimler Enstitüsü, Klinik Psikoloji Bölümü, Işık Üniversitesi, İstanbul.

Gündoğdu R., Yavuzer Y. ve Karataş Z. (2011). Eğitim Fakültesi öğrencilerinin çatışma çözme becerilerinin ve kaygı düzeylerinin incelenmesi. e-Journal of New World Sciences Academy, 6(1), 341- 361. 
Hisli, N. (1989). A reliability and validity study of Beck Depression Inventory in a university student sample. J. Psychol., 7, 3-13.

Hunt, J. and Eisenberg, D. (2010). Mental health problems and help-seeking behavior among college students. Journal of Adolescent Health, 46(1), 3-10.

Kashdan, B.T. (2007). Social anxiety spectrum and diminished positive experiences: Theoretical synthesis and meta-analyss. Clinical Psychology Review, 27, 348-365.

Kaya, M. ve Varol, K. (2004). İlahiyat fakültesi öğrencilerinin durumluk-sürekli kaygı düzeyleri ve kaygı nedenleri (Samsun örneği). Ondokuz Mayıs Üniversitesi İlahiyat Fakültesi Dergisi, 17(17), 31-63.

Kermen, U., Tosun, N. İ., ve Doğan, U. (2016). Yaşam doyumu ve psikolojik iyi oluşun yordayıcısı olarak sosyal kaygı. Ĕ̆itim Kuram ve Uygulama Araştırmalarn Dergisi, 2(1), 20-29.

Keyes, C. L., Eisenberg, D., Perry, G. S., Dube, S. R., Kroenke, K. and Dhingra, S. S. (2012). The relationship of level of positive mental health with current mental disorders in predicting suicidal behavior and academic impairment in college students. Journal of American College Health, 60(2), 126133.

Kula K. Ş. ve Saraç T. (2016). Üniversite öğrencilerinin gelecek kaygisı. Mustafa Kemal Üniversitesi Sosyal Bilimler Enstitüsü Dergisi, 13(33), 227-242.

Kulygina, M. and Loginov, I. (2015). Students mental health and multistage prevention programme: The Russian experience. Mental Health $\mathcal{E}$ Prevention, 3(1-2), 17-20.

Öner, N. ve Le Compte, A. (1985). Durumluk - sürekli kaygı envanteri el kitabı. (2. Basım). İstanbul: Boğaziçi Üniversitesi Yayınları.

Öztürk, A. (2008). Manisa Celal Bayar Üniversitesi Beden Eğitimi ve Spor Yüksekokulu öğretmenlik programı öğrencilerinin durumluk ve sürekli kaygı düzeyleri ile akademik başarıları arasındaki ilişki. (Master's thesis) Pamukkale Üniversitesi Sağlık Bilimleri Enstitüsü, Sporda Psiko-Sosyal Alanlar Anabilim Dalı, Denizli.

Özbay, G. (1997). Üniversite öğrencilerinin problem alanlarını belirlemeye yönelik bir ölçek geliştirme: geçerlik ve güvenirlik çalışması. Yayımlanmamış yüksek lisans tezi. Karadeniz Teknik Üniversitesi, Sosyal Bilimler Ensitüsü, Eğitim Bilimleri Ana Bilim Dalı, Trabzon.

Joeng, J. R. and Turner, S. L. (2015). Mediators between self-criticism and depression: Fear of compassion, self-compassion, and importance to others. Journal of Counseling Psychology, 62(3), 453. 
Lee, C., Dickson, D. A., Conley, C. S. and Holmbeck, G. N. (2014). A closer look at self-esteem, perceived social support, and coping strategy: a prospective study of depressive symptomatology across the transition to college. Journal of Social and Clinical Psychology, 33(6), 560-585.

Mortier, P., Demyttenaere, K., Auerbach, R. P., Green, J. G., Kessler, R. C., Kiekens, G. and Bruffaerts, R. (2015). The impact of lifetime suicidality on academic performance in college freshmen. Journal of Affective Disorders, 186, 254-260.

Michael, K. D., Huelsman, T. J., Gerard, C., Gilligan, T. M. and Gustafson, M. R. (2006). Depression among college students: Trends in prevalence and treatment seeking. Counseling \& Clinical Psychology Journal, 3(2), 60-70.

Nordstrom, A. H., Goguen, L. M. S. and Hiester, M. (2014). The effect of social anxiety and self-esteem on college adjustment, academics, and retention. Journal of College Counseling, 17(1), 48-63.

Öner, N. and Le Compte, A. (1983). Durumluk-Sürekli Kaygı Envanteri. İstanbul: Boğaziçi Üniversitesi Matbaası.

Rada, S. (2018). Üniversite öğrencilerinin erken dönem uyumsuz şemalar ile sosyal kaygı düzeyleri arasındaki ilişkinin incelenmesi: Türkiye ve Belçika karşılaştırması. (Master's thesis). Sakarya Üniversitesi, Eğitim Bilimleri Enstitüsü, Eğitimde Psikolojik Hizmetler Bilim Dalı, Sakarya.

Şahin Baltacı, H. ve Küçüker, D. (2017, Mayıs). Pamukkale Üniversitesi Psikolojik Danışma ve Rehberlik Eğitim, Uygulama ve Araştırma Merkezine İlişkin İhtiyaç Analizi. IV. International Eurasian Educational Research Congress'te sunulan bildiri, Pamukkale Üniversitesi, Denizli.

Şahin Baltacı, H., Küçüker, D., Özkılıç, I., Karataş, U. Y. ve Özdemir, H. A. (2021). Investigation of variables predicting depression in college students. Eurasian Journal of Educational Research, 92, 211-225.

Şart, Z. H., Börkan, B., Erkman, F. ve Serbest, S. (2016). Resilience as a mediator between parental acceptance-rejection and depressive symptoms among university students in Turkey. Journal of Counseling E Development, 94(2), 195-209.

Sherer, M. (1985). Depression and suicidal ideation in college students. Psychological Reports, 57(3), 1061-1062.

Soykan, Ç., Özgüven, H. D. ve Gençöz, T. (2003). Liebowitz social anxiety scale: the Turkish version. Psychological Reports, 93(3), 1059-1069.

Spielberger, C. D. (1966). Theory and research on anxiety. In C. D. Spielberger (Ed) Anxiety and behavior, 3-20. San Diego, CA: Academic Press. 
Taşkın, E. O. vd., (2005). Depresyonlu hastaların depresyona yönelik tutumları. Türkiye'de Psikiyatri, 7(2), 44-53.

Tektaş N. (2014). Üniversite mezunlarının kaygı düzeylerinin incelenmesi. Selçuk Üniversitesi Sosyal Bilimler Enstitüsü Dergisi, Dr. Mehmet YILDIZ Özel Sayist, 243- 253.

Ulas, B., Tatlibadem, B., Nazik, F., Sonmez, M. ve Uncu, F. (2015). Üniversite öğrencilerinde depresyon sıklı̆̆ı ve ilişkili etmenler. Celal Bayar Üniversitesi Sağllk Bilimleri Enstitüsü Dergisi, 2(3), 71-75.

Ünal vd., (2010). Üniversite öğrencilerinin ruhsal hastalığa yönelik inançları. Düşünen Adam, 23(3), 145-150.

Yazgan-İnanç, B ve Yerlikaya, E. E. (2014). Kişilik kuramları. 9.baskı. Ankara: Pegem Akademi.

Yeşilyaprak, B. (1985). Üniversite gençlerinin psikolojik sorunları. Eğitim ve Bilim, 10(57), 32-37.

Weigold, I. K. and Robitschek, C. (2011). Agentic personality characteristics and coping: Their relation to trait anxiety in college students. American Journal of Orthopsychiatry, 81(2), 255-264.

Westefeld, J. S., Casper, D., Galligan, P., Gibbons, S., Lustgarten, S., Rice, A., Rowe-Johnson, M. and Yeates, K. (2015). Suicide and older adults: Risk factors and recommendations. Journal of Loss and Trauma, 20(6), 491-508.

Wynaden, D., McAllister, M., Tohotoa, J., Al Omari, O., Heslop, K., Duggan, R., and Byrne, L. (2014). The silence of mental health issues within university environments: A quantitative study. Archives of Psychiatric Nursing, 28(5), 339-344.

\section{Kaynakça Bilgisi / Citation Information}

Şahin Baltacı, H., Küçüker, D., Karataş, U. Y., Özkılıç, I. ve Özdemir H. A. (2021). Psikolojik Danışma Merkezine başvuran üniversite öğrencilerinin depresyon, sosyal kaygı, durumluk ve sürekli kaygı düzeylerinin incelenmesi. OPUS- Uluslararası Toplum Araştırmaları Dergisi, 18(Eğitim Bilimleri Özel Sayısı), 4718-4745. DOI: 10.26466/opus.904430. 